\title{
WTO-Analysis of Issues with the Dispute Settlement Mechanism
}

\author{
Dharmapuri Selvakumar Madhumitha, B.com Llb (Hons) \\ Tamil Nadu National Law University, Tiruchirapalli, India \\ Email: madhumithads865@gmail.com
}

How to cite this paper: Madhumitha, D. S. (2020). WTO-Analysis of Issues with the Dispute Settlement Mechanism. Beijing Law Review, 11, 879-888.

https://doi.org/10.4236/blr.2020.114052

Received: November 17, 2019

Accepted: December 8, 2020

Published: December 11, 2020

Copyright (C) 2020 by author(s) and Scientific Research Publishing Inc. This work is licensed under the Creative Commons Attribution International License (CC BY 4.0).

http://creativecommons.org/licenses/by/4.0/

\begin{abstract}
World Trade Organisation is one of the main international organisation dealing with rules regulating trade between nations. The main goal of the WTO is to regulate, negotiate business among the exporters and importers with the goods and services. This organisation gives a forum in case of dispute for the governments to step up and provide their agreements to get in consensus with their problems. World Trade Organisation is basically not a separate organisation with its own nomination, it is an organisation run by member government parts of WTO system. WTO played a very important role in boosting economic prosperity and mend relationships among the governments by providing Multi-Lateral agreements, its roots are there to be found from the silk road creation to the set-up of GATT. Even the DSP playing an important role in the development of economic relations, it has backlash on its own, the dispute settlement mechanism within the WTO system has been facing many problems regarding the decision of the forum, their competency, their qualification, the biasness within the forum to support the favouring states. The 2017 annual report by DSB Chair, Ambassador Sunanta the reports stated that there was complication with the complex dispute resolution such as the plain packaging case, too many cases reported undecided, the resource occupation suggested a problem, for example, Airbus and Boeing proceedings. The 2019 report showed that there was decrease in overall economic activity in the global trade. The project analyzes the issues with the dispute settlement mechanism in the WTO and the ways and suggestions to overcome the situations.
\end{abstract}

\section{Keywords}

Dispute, Issues, International Organisation, Rules, Governance

\section{Introduction}

"Dispute settlement is the central pillar of the multilateral trading system, and 
the WTO's unique contribution to the stability of the global economy. Without a means of settling disputes, the rules-based system would be less effective because the rules could not be enforced. The WTO's procedure underscores the rule of law, and it makes the trading system more secure and predictable. The system is based on clearly-defined rules, with timetables for completing a case. First rulings are made by a panel and endorsed (or rejected) by the WTO's full membership. Appeals based on points of law are possible".

To any success of multilateral trading system, the achievement of smooth and clear transaction is owed to the Dispute settlement body, as without any body which wouldn't settle the disputes, the trade, economy and the rules on which the agreement is formed would be null and void. If a member feels any violation of the rules by another member, the dispute settlement mechanism is invoked. Usually, it will be when a trade policy adopted by one-member country is violating the trade agreements and WTO agreements that are entered into by the parties. In consonance with this, even the third group of countries can declare their interest towards the dispute.

\section{Research Question:}

1) Whether there is a dispute settlement mechanism in WTO?

2) Is it effective and efficient in performance of dispute settlement? If so, what method does WTO use?

Research Objective:

- To study and understand the nature and importance of WTO.

- To analyse the dispute settlement mechanism and its methods used by WTO in day to day practice.

- To critically review whether the dispute settlement mechanism is efficient and effective in WTO.

\subsection{History of Dispute Settlement System}

It was the start of the Uruguay round which paved way for the establishment of the Dispute Settlement. But even before that GATT 1947 took the initiative for having the mechanism of dispute settlement system over 50 years (WTO, DSS Training module: Chapter 12). There were rules under Art.XXIII (2) of GATT 1947 that in case of any disputes initially the parties in joint have to deal with it and resolve. After which the whole process got into resolution in the hands of the representatives of the contracting parties who are interested along with those in dispute, they were referred to as working parties. The decision was made through consensus. However, there was a whole shift as they converted into panel system of 3 - 5 of people who are outsiders, not involved in the dispute, totally unrelated. Recommendations, rulings, were submitted through a report that is written independently (WTO, DSS Training module: Chapter 12). Such reports in turn will be submitted to the GATT Council who will decide on the validity of the settlement. Upon the approval, the reports become binding on the disputed parties. 
The questions such as what pulled to the downfall of GATT's dispute settlement mechanism? Were there any weakness that was in GATT arise here. Even though the Uruguay round paved way for WTO Dispute settlement system, the positive characteristic was taken from the GATT 1947: the positive consensus (WTO, Introduction to DSS: Chapter 1). For referring a dispute to the panel, a positive consensus (i.e., no objection should be obtained from the contracting parties) is required to be arrived at. For every step including authorization of report, the countermeasures against the unobliging party. what was quite outside was that the parties who are not involved in the dispute was not barred from participating in the decision making process (WTO, DSS Training module: Chapter 2). The respondent in certain cases may block the consensus. Then the question such as, if the respondent is going to lose then he may as well as block the consensus may arise. But quite surprisingly, in the past not many used the veto power as it may affect the parties in the long run to maintain cordial relationship. so mostly the reports were accepted. This was only too the disputes that were brought before the GATT Panel however there where many disputes which hasn't been brought in lack of faith in the panel system and reports, where the respondent may use his veto power thus this power weakened the objective of the dispute settlement system. When the panel realized that there needs to a diplomatic solution rather than one side favouring judgements as the opposition respondent may veto the report, had structurally weakened the GATT DSS. (WTO, DSS Training module: Chapter 2).

\subsection{Tokyo Codes}

Multilateral trade negotiations from the Tokyo round formed many plurilateral agreement whereby the Tokyo codes were established, where it contains code specific dispute settlement procedures and such codes were only applicable to signatories (The GATT years). Usually the member of both Tokyo round and GATT 1947 system had the option of "Forum Shopping" where the dispute settlement system maybe chosen on the most beneficial one. Under GATT 1947 it was mostly favourable as they can block the report thus many disputes were turned unfavourable (WTO: Legal texts).

\subsection{The Uruguay Round 1989}

1980's faced many trade related problems since the GATT 1947 Dispute settlement system wasn't functioning properly to the best interest of trade and commerce on both developing and under-developed countries. Many trade related countries felt the need for structural strengthening as well as administratively. It defined the stages of procedure in structure for dealing with the disputes. In introduce the length of time in which the case can be settled along with flexible deadlines according to case to case basis. A prompt settlement is essential for the settlement and WTO to function in an effective and proper manner (WTO, Historic Development). The deadline for a case on a first ruling is one year 15 
months for appeal. Sometimes when it is necessary for the case to be pushed and is urgent to be resolved, the flexible time date will turn into a fixed date and will be resolved faster.

The Uruguay rounds also removed the concept and made it impossible for the losing country to block the adoption of the ruling. As before, in GATT by single objection the ruling could be not adopted thus resulted in many unresolved conflicts, thereby affecting the trade and commerce economy (WTO, Historic Development). The round also made it possible for the losing country to block if only they convince the other members to form majority consensus. The first step is the consultations with the government to discuss their problems etc.

\section{Dispute Settlement}

The dispute is settled by the dispute settlement body, they undertake the responsibility to see that the dispute is beneficial and diplomatically settled. The body consists of all the members of WTO. The body also uptakes the function of creating the panel for the settlement of disputes, they also reserve the sole right to accept or reject the reports and findings of the settlement arrived at by the panel. "It monitors the implementation of the rulings and recommendations, and has the power to authorize retaliation when a country does not comply with a ruling" (WTO: DSS Training module, Chapter 3).

\subsection{Stages of Dispute Settlement}

First Stage: consultation with the respective parties' government of the dispute. Consultation will go upto 60 days. Before going for the settlement panel to resolve, the countries have to exhaust their discussion system within themselves to discuss and settle their differences. Sometimes on failure, they may even request the director general of WTO to act as the mediator and settle the dispute (WTO, Unique Contribution).

Second Stage:

The panel is appointed in case of a request by the parties to the dispute on a failure to reach a consensus on their dispute usually, the appointment if requested takes upto 45 days. "In the dock" country may block the panel appointment but if the dispute settlement body meets for the second time then no blockage can be done. Unless a consensus against the appointment of the panel is reached to the maximum (WTO, Settling disputes). Thus, it can be said that the panel has the authority to make rulings and accept the findings. The rejection can only be done by the dispute settlement board thus making it difficult for the losing party to reject the report of the panel. The findings and the report have to be given by the panel within the time of 6 months to the parties to the dispute. However, the timeline for resolving any dispute to perishable goods is reduced to 3 months.

Appeals:

Any party to the dispute can appeal to the appellate body which is set by the 
dispute settlement body of 7 members, who are wide representatives of the members of WTO. Such law and legal interpretation is the only basis on which the appeal can be made, just like High Court no trial such as revisiting the evidence or examination of witnesses can be done. The appeal can do any of the following: 1) Uphold 2) Modify 3) Reverse the panel's findings. The appeal shall last for minimum of 60 days and extend to 90 days. The Acceptance or rejection lies in the hands of the Dispute settlement body but a rejection can be achieved only on consensus (WTO, DSS Training Module: Chapter 6).

The country against whom the settlement is made should follow the reports according the agreement and recommendations. Any country can complain against the inactivity of the respondent in complying with the report. The respondent will be given time which is reasonable enough on case to case basis to clarify. If it fails, negotiation has to be entered into so that the compensation and agreement which is accepted mutually can be decided. It will take time up to 20 days, if even after enough time period no consensus as to compensation is arrived at, the Dispute settlement body is asked to step in. which can order for other Countries to suspend concessions for a temporary period to see if the non-complying country complies. The dispute settlement orders this within 30 days' time (WTO, Legal texts).

\subsection{Issues in the DSU}

The WTO Dispute settlement has brought many success and compromise in trade between the contracting states in Multilateral agreement in many cases however the most concern that the dispute settlement system faces is the systematic and legitimacy problems. The new resolutions thought it brought carefree and good trade relations and peaceful settlement of dispute solving but what it really did was imposition of trade sanctions and non-enforcement of the report by the dispute settlement due to their national laws sometimes lead to limiting the trade (Junichi Ihara, 2017).

\section{Constitutional Issue}

First and foremost, the countries which are part of WTO agreement have a distinct Sovereignty upon which they operate, it has got itself a legislative function and economic social status according to their differences in operation. The domestic legislation is most likely the dispute between parties. Art.XVI.4 "[e]ach Member shall ensure the conformity of its laws, regulations and administrative procedures with its obligations as provided in the annexed Agreements" (WTO Agreement, Art.XVI. 4). When there are any difference of opinion and a dispute arises, the attack is directly on the domestic law being inconsistent with the GATT, 1994 provisions. For example, when the internal tax is imposed by the government of one country on a imported goods, the question won't regarding on whether tax imposed by respondent in certain shipment is violative of the provisions of GATT but the challenge will be directly on the internal law being 
inconsistent. The dispute rather than addressing the application questions the consistency of the law itself, in other words it is directed to the law. When a dispute arises on the WTO platform the Dispute settlement board when it has to look into the subject matter of dispute. Whether the dispute settlement body has the jurisdiction to validate the domestic law in consistency with the GATT provisions. Whether such would be allowed in the appellate jurisdiction? In case of the question being a question of fact such will not be given for review (WTO, DSS Training module: Chapter 10).

Moreover, the WTO secretariat has initiated itself with a position of legislature doing legislative actions through the dispute settlement function if there exist any ambiguities that are needed to fill the trade gaps. In this accord only the panel has the absolute right, the nations which are member states to the agreement can never really voice in much out except in refusal of majority. There has been violation because no such consent for the powers was taken from the member states.

Other decisions are now emerging that continues this process of legislation by the WTO Secretariat. For instance, in EU Bed Linens (WTO, Report XVT/DS141/R) the panel struck down the EU practice of "zeroing" out negative dumping margins for certain product models to ensure that the final overall dumping margin reflected the full amount of dumping targeted to certain other product models. This practice is necessary to remedy the full amount of dumping of the targeted products. The panel decided that there is not explicit prohibition of practice of text in Antidumping Agreement but still the panel concluded that there is violation and the practice is inconsistent with the agreement. When such a decision is made by the panel to fill the legislative gap, why wouldn't the member states not doubt their competency (Agreement on Art.VI of GATT, 1994).

In Thailand-H-beams, (WTO, Thailand Anti-dumping duties, 2000) on the fifteen injury factors in the Antidumping Agreement, the WTO panel faulted the Thai authority to make any specific findings. They asked for a persuasive explanation on how each factor mentioned in the agreement led to the injury However, the list of factors in Antidumping Code Article 3 was never intended to be treated this way. Usually in a case, the material facts just be it in numbers two or three is enough for consideration and leaving out the irrelevant points. However, on certain circumstances the authorities do tend to treat certain factors as important as others. The panel's reasoning here, however, suggests that if any of the fifteen factors gives the appearance of healthy domestic industry, then the authority must rule for respondents (in other words, find no injury). This type of review is not the minimal way or the standard way of reasoning for addressing an issue and a provision. The appellate body have reversed most of the reviews of the panel" (WTO, Report WVT/DS122/7, 2001).

There are two things which are threatening the WTO Dispute settlement system as discussed by the Appellate Body's Annual Report of 2017 not only ques- 
tioning the existence of the system but also its legitimacy.

- Facing Complex issue.

- Way in which the DSU should resolve its disputes (WTO, Unprecedented Challenges).

It is no doubt that the appellate body of the WTO DSU is there to facilitate smooth transaction of trade from the time it was started, it had faced and solved disputes around 551 disputes initiated by members. There have been almost 230 panel reports and 136 appellate board decisions. But what really counts here is the active initiation and implementation of the decision taken by the dispute settlement board by the member countries of WTO. The appellate body given with more number of trade related issue with given number, size and complexity of the disputes, it is not feasible to think that Appellate body would give a higher quality report as there is a specific time frame within which the DSU has to deliver Wolff, Alan Wm. (2001). Many initiatives have been taken by the appellate board to try and work things out by solving the disputes amicably and with quality by providing a complete report which includes their findings, conclusion and also the reasoning for the decision-making process. they are trying harder to make less use of the limited resource available to sort out the issue diplomatically between the parties. But only with allocation of specific resources and making a definite procedure which can compensate for the workload that has been put forth. For example: discussion of deadlines and extending it further on the complication of the cases basis. The efficiency of the system can only be improved by changing the procedures and by improving the delays.

\section{Institutional Issues}

1) Competence: The qualification of the panellist selected by the Dispute settlement board is not seen much and on what basis the report made by them is competent to be followed by a country and their laws are answer yet to be made.

2) Bias: panellists are usually from the Bigger representation countries, on basis of their satisfaction and trade relations with other countries and their previous encounters there may be biasness on part of the panellist in making a report as per the DSU.

3) Transparency: it is claimed that most of the proceedings of WTO DSU are made in secret. The panel hearings are supposed to be in camera proceedings.

\section{Suggestions}

1) There can be a safety valve for solving the dispute settlement between the parties where there is no legislative competency to be discussed in issue, non-binding decisions settlement functions such as forced conciliation, mediation and voluntary arbitration before going to the panel for settling their disputes, thereby the domestic laws can also be protected for deciding on their competency, the number of disputes will be less which the DSU will take time to solve other issues before the delay times arrives. And the parties can resolve the 
conflict amicably before going for a forum with a much more complication procedure where there will be trade sanctions in case of non-implementation of the binding decisions by fellow member states thereby hampering the trade process without any dictation.

2) The alternative for compensating for the trade violations should be looked into for very serious violations. Usually they offer trade liberalization as means of compensation for the fact of violation by offensive trade practice. Means by fines and charges will not improve the quality of the trade relations that exists in WTO.

\subsection{Constitutional Issue Solution}

Rather than taking up the WTO dispute settlement reports and panel reports has final binding decision as they maybe appointed as the representative member of the member states that are present in the WTO, a standing judiciary maybe created to discuss and touch upon the issue of the consistency of the law with the WTO agreement and GATT. The sovereignty can be questioned at this stage as well, stating that it will create a binding decision on a law which is domestic in nature to be decided. However this can be solved easily by making the decision of the panel of Judges as binding.

Even though there maybe a little bias and conflicts with the judicial system, the bias which exists with the member state to be on the panel of dispute resolution is way higher, as they are the representatives of the country which is also a part of WTO agreement. To make alright certain transactions or trade relations they may actually favour a particular party even though they maybe outsider to the dispute. Judicial system having renowned Judges with expertise and knowledge of law, agreements, treatise and solving disputes, it would be balance of powers. They must however impose restrictions upon themselves.

\subsection{Institutional Issues Solution}

Expert: Make available expertise on the panel, who are not the representatives from the WTO member states. This way the biasness and competence can left out from the discussions. Judges are experts in what they look into.

Judiciary: There shouldn't be settlement beneficial to all, there can be arguments, evidences, facts which can persuade the judges from making decisions based on a firm reasonable ground which maybe transparent in nature, as the judgement copy with the validity can be dealt. Judiciary should be an independent body with their own time limit and fixtures of procedures.

\section{Conclusion}

Dispute settlement system is for the smooth functioning of the trade and commerce relations between the WTO member states. It is entrusted with the activity of solving disputes only because the members of the panel are chosen from their own member states to dispute. Even though trade sanctions are utmost for 
non-compliance, the sanctity of why the body does it in what authority is a question. That question can be answered by stating that the member states entrusted their dispute settlement to the DSU on the date of signing the agreement. The problem starts when the panel starts the legislation process stating the competency of the domestic law or internal law in consonance with the agreement and GATT is the main question. There should be compulsory ADR settlement process before, in exhaustion of it, they can approach the DSU. The DSU has too many cases to be solved within a limited period of time which is heavy work load and cost. This can be prevented throughout of DSU settlement procedure which is non-binding.

The constitution of legal structure should be effective, structured and not biased. The judges and staff should follow the procedures of law and must be well constituted. When they decide, the fairness and honor should be credited accordingly. This even leads to open procedures, open judgements, thus dealing away with transparency.

Before any damage is done to the trade and commerce effective functioning, there is a need for urgent change in the WTO Dispute Settlement system.

\section{Conflicts of Interest}

The author declares no conflicts of interest regarding the publication of this paper.

\section{References}

Evaluation of the WTO Dispute Settlement System: Results to Date, DSS, Training Module: Chapter 12.

https://www.wto.org/english/tratop e/dispu e/disp settlement cbt e/c12s2p1 e.htm

Junichi Ihara (2017). WTO, WTO Dispute Settlement Body-Developments in 2017. https://www.wto.org/english/tratop e/dispu e/ihara 17 e.htm

The GATT Years: From Havana to Marrakesh. https://www.wto.org/english/thewto e/whatis e/tif e/fact4 e.htm

Wolff, A. W. (2001). Problems with WTO Dispute Settlement. Chicago Journal of International Law, 2, Article 14. http://chicagounbound.uchicago.edu/cjil/vol2/iss2/14

World Trade Organization (2000). Report of the Panel, European Communities-Antilumpimg Duties on Imports of Cotton-Type Bed-Linen from India, XVT/DS141/R.

WTO (2018). "Unprecedented Challenges" Confront Appellate Body, Chair Warns. https://www.wto.org/english/news e/news18 e/ab 22jun18 e.htm

WTO Agreement Art. XVI.4.

WTO. A Unique Contribution, Understanding the WTO: Settling Disputes. https://www.wto.org/english/thewto_e/whatis e/tif_e/disp1 e.htm

WTO. Historic Development of the WTO Dispute Settlement System, Dispute Settlement System Training Module: Chapter 2. https://www.wto.org/english/tratop e/dispu e/disp settlement cbt e/c2s1p1 e.htm

WTO. Introduction to the WTO Dispute Settlement System, Dispute Settlement System Training Module: Chapter 1.

https://www.wto.org/english/tratop_e/dispu e/disp settlement_cbt_e/c1s1p1_e.htm 
WTO. Legal Issues Arising in WTO Dispute Settlement Proceedings, Dispute Settlement System Training Module Chapter 10.

https://www.wto.org/english/tratop e/dispu e/disp settlement cbt e/c10s8pl e.htm

WTO. Legal Texts: The WTO Agreements. https://www.wto.org/english/docs e/legal e/ursum e.htm\#Understanding

WTO. The Process-Stages in a Typical WTO Dispute Settlement Case, Dispute Settlement System Training Module: Chapter 6.

https://www.wto.org/english/tratop e/dispu e/disp settlement cbt e/c6s1p1 e.htm

WTO. WTO Bodies Involved in Dispute Settlement Process, DSS Training Module: 3. https://www.wto.org/english/tratop e/dispu e/disp settlement cbt e/c3s1p1 e.htm\#d ecision making 